\title{
Uma realidade que ficcionalizou a si mesma: história e subjetividade em Vento sul, de Vilma Arêas
}

Ana Paula Pacheco ${ }^{1}$

Um traço forte de certa ficção brasileira contemporânea é a desliterari-

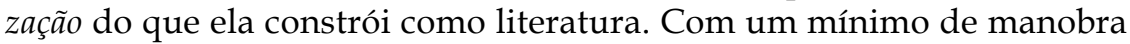
ou o máximo de sinceridade, trata-se de apresentar ao leitor histórias mais ou menos reais, sem correspondência com o que convencionalmente se definiu por "literatura de imaginação": destinos individuais fortemente marcados pelas circunstâncias do país e do mundo, biografias magras ou resumidas, episódios decisivos e sem ênfase. À primeira vista, dispensa-se o fingimento, que deixa de ser o seu dispositivo artístico essencial, como se a matéria falasse por si mesma. Logo o estranhamento suspende a impressão de "coisa pronta" e "fácil de digerir": se a linguagem é límpida e o artifício, pouco, ressalta-se a carga de perplexidade e imaginação que a própria vida, tudo que a recobre, tratou de providenciar - e cujos nexos a ficção ensaia. A aparência não fictícia que essa ficção transformou em estilo faz parte de um sistema de mediações artístico e aponta contraditoriamente para a defasagem do real em relação a si mesmo. Sua matéria opaca, cheia de falsas entradas, é um desafio dos mais complexos, pois a realidade não está disponível nem é fácil de alcançar. Contudo ela existe. Pode-se supor que a crescente abstração de nossas vidas - subordinadas ao poder de desrealização do capital, com consequências bastante concretas - talvez seja um dos motivos da proeminência da realidade na literatura brasileira das últimas décadas.

Não sendo em si mesmo novo, mas sem dúvida ressignificado pelo quadro atual, esse caminho da mimese remete a linhagens antiestetizantes do Modernismo, e entre nós particularmente à lição da poesia modernista. A novela "Ciro", de Modesto Carone, juntamente com "Resumo de Ana", ambos parte de Resumo de Ana, são, a meu ver, os exemplos mais bem acabados dessa desliterarização. ${ }^{2}$

\footnotetext{
${ }^{1}$ Doutora em teoria literária e literatura comparada, professora do Departamento de Teoria Literária e Literatura Comparada da Universidade de São Paulo (USP), São Paulo, SP, Brasil. E-mail: anapaulapacheco@usp.br

2 Em "Ciro", o ciclo do nacional-desenvolvimentismo é visto nos efeitos palpáveis sobre a vida dos de baixo, com as reviravoltas, oportunidades e quedas bruscas a que submeteu o trabalhador comum. A sequência grande de ocupações (Ciro foi carregador de malas, balconista, operário, garçom, linotipista, dono de gráfica, novamente carregador, jardineiro, vendedor ambulante) termina retornando ao ponto de origem, a pobreza. Numa alusão interna ao texto, as mudanças na vida de Ciro remetem ao poema "Tragédia brasileira", de Manuel Bandeira, mas em lugar da instabilidade amorosa da ex-pros-
} 
No cinema, esse processo é observado com clareza nos documentários de Eduardo Coutinho, nos quais fica claro o quanto a realidade ficcionalizou a si mesma, razão da necessidade de proceder às avessas com a ficção. Estudando o paradoxo, como se pode ver em Jogo de cena, a câmera de Coutinho acompanha episódios marcantes da vida privada, no mais das vezes perdas relativas ao âmbito da família, obrigando a pensar o sentido de uma experiência histórica em que não se distinguem encenação e verdade, realidade e reality show, tragédia pessoal e logro, espetáculo e sofrimento, desabafo e desamparo.

Vale observar que se trata ainda de um documentário, e não de um jogo de relativização da realidade e da ficção; por outra, o que há de escorregadio entre os dois campos é historicamente determinado. Se as pessoas que contam os episódios por elas vividos se assemelham a personagens, e poucas vezes o contrário, isso se dá porque a vida parece convertida em imagens à procura de um corpo. Assim, tendo por base o depoimento pessoal, o documentário faz ver "por dentro" a impenetrabilidade do mundo contemporâneo, que é cotidiana. O resultado é uma sequência de retratos, com nexo próprio, em que cada subjetividade se caracteriza por uma espécie de singularidade negativa, ou às avessas, a qual remete a um processo de individuação pautado mais pela resistência ao que a vida impôs do que propriamente pela constituição de um sujeito (Naves, 1999). O traçado ímpar compõe-se de faltas mais ou menos identificáveis, resultando singular por não corresponder a um percurso em que a passagem do tempo e a formação de um "eu" fossem, em regra, correspondentes.

Como um conjunto de traços vincados pela perplexidade diante dos atropelos reservados por um destino histórico que surpreende quem os vive como se fosse alheio, mas também marcados pela luta pessoal diante dos reveses e perdas sofridas, tal singularidade paradoxalmente as aproxima de figuras que parecem "de ficção" (pela coerência do caráter, todavia desintegrado). Curiosamente, segundo o depoimento de uma das atrizes que interpretam, duplicando, o relato das personagens reais, a sensação ao encenar é de defasagem (Jogo de cena, 2007). Contra o fundo da outra cena, "real" - mesmo que já "de segundo grau", pois se trata de relatos feitos por pessoas reais no palco de um teatro -, a encenação das profissionais por vezes dá a impressão de "mentira", como diz uma atriz da Rede

\footnotetext{
tituta que, livre da pobreza, quer aproveitar a vida namorando, Modesto Carone coloca a instabilidade do trabalho no país que "se desenvolve", a qual atinge em cheio os mais pobres ou os que pareciam estabilizar-se noutro patamar pela via do esforço pessoal. Alterando, portanto, os termos do problema, a dimensão privada da catástrofe ganha outra ressonância, remetendo mais imediatamente a problemas da esfera pública da existência (Carone, 1998).
} 
Globo, sobre a insuficiência da representação frente à força - inventiva, diríamos, tortuosa - da própria realidade.

O mais recente livro de Vilma Arêas, Vento sul, tem lugar próprio nesse quadro. A marca mais saliente do conjunto está numa particular dinâmica de apreensão da experiência vivida, ou melhor, de suas linhas paralelas e fugidias. Os textos trazem dois temperamentos: um deles mais épico, no qual encontros decisivos e marcadamente desavindos remetem à contundência das dificuldades materiais, da violência familiar, da fratura social, que muitas vezes dão o ponto decisivo dos destinos individuais narrados; outro mais lírico, em que a poesia vem em auxílio à rememoração e ao esquecimento - ou é o seu caminho escolhido -, retendo em parte a substância de perguntas irrespondíveis. Na maioria dos relatos, o artifício literário, às vezes exacerbado, é posto a nu, ao passo que se busca a verdade sobre as vidas e as mortes narradas. Isto é, a desliterarização, dada pelos episódios, espaços e personagens (que poderiam ser e no mais das vezes de fato são) reais, cerca-se de expedientes literários nos quais o sujeito se apoia para tocar o real. Mas quase sempre eles são claramente isto: artifícios em que a vida emerge por contraste. Como na casa que alguém constrói cercando ausências (veja-se o conto "Habitar"), a literatura, e de modo geral a arte, escora os narradores, de tal modo que o artifício não escamoteia ou "ultrapassa" a realidade, antes procura conhecê-la. É o caso da feição mais difícil e resistente que a linguagem assume para apreender a distância entre pessoas de carne e osso, estabelecida pela desigualdade social (no extraordinário "Linhas e trilhos"); ou para apreender cisões tão constitutivas como indevassáveis (o suicídio do pai de uma menina pequena, guardado pelo esquecimento em "Zeca e Dedeco"); ou tão inescapáveis a ponto de a arte não trazer rota de fuga sem mentir a si mesma (em "Sister, 1982", as personagens Fausto e Margarida figuram em telas separadas, redobrando a distância quando a morte se interpõe entre os amantes reais, Fausto e Vilma; noutra tela, separado de Margarida por uma paisagem emoldurada, Fausto se volta com muita intensidade para ver, não o que olha, pois é cego, mas o que imagina: a realidade).

Em algumas narrativas, porém, as técnicas literárias se autonomizam, distanciando-se desse trabalho de desestetização. São histórias mais desembaraçadas e, no entanto, ou por isso mesmo, mais artificiosas. Veja-se nesse sentido o deslizamento tão humorado quanto virtuosístico entre fingimento e realidade em "Canto noturno de peixes": como se a ficção se equilibrasse sobre um jogo de palavras, a imagem de uma pescadora confunde-se com a de uma sereia distraída, a qual, esquecendo-se de cantar, passa de sedutora a seduzida, num quartinho sem janela, de onde não 
se vê o mar. No conto "Nem todos os gatos", o jogo também engenhoso aponta de modo ambíguo para sua matéria congênere: o desmanche e a espetacularização do real. A pseudointegração do país pela mídia e pelo consumo de tudo e todos se traduz na (leve) crise de um repórter diante das imagens da brutalidade social transformada em dramalhão, que a despeito da consciência, ele continua a reproduzir no texto escrito sob encomenda. O domínio técnico da narrativa, paralelo ao do narrador em crise, impressiona o leitor e promete perspectiva crítica, entretanto o andamento mais lépido, ou o traço lúdico, impresso à matéria narrativa por esse mesmo domínio técnico, dá o que pensar.

É, pelo contrário, nos textos mais francos e complexos que a voltagem crítica de Vento sul cresce - destacadamente, as narrativas iniciais da primeira seção, "Matrizes", nas quais procedimentos de montagem, baralhamento e variação de pontos de vista dão combate à perda de perspectiva que solapou a realidade. A meu ver, elas formam a parte mais decisiva do volume, a que outros textos afluem, como em busca de seu chão histórico. A fábula que serve de epígrafe ao livro diz respeito em especial a esta seção, mas é sugestiva da báscula entre artifício e verdade em quase todos os textos, fazendo pensar na proximidade entre artifício e expediente necessário - uma das verdades do fingimento - quando se está na posição da ovelha. Vale a pena reproduzi-la:

Un pastor se encuentra con un lobo.

- !Qué hermosa dentadura tiene usted, señor lobo! - le dice.

- !Oh! - responde el lobo - mi dentadura no vale gran cosa, pues es una dentadura postiza.

- Confesión por confesión, entonces - dice el pastor -; si su dentadura es postiza, yo puedo confesarle que no soy pastor: soy oveja. (Braulio Arenas)

O diálogo é entre uma ovelha e um lobo, mas a fábula começa dizendo que um pastor se encontra com um lobo, e de fato só sabemos tratar-se de uma ovelha na última fala. O disfarce quase a salva, mas afinal a realidade não é somente a aparência e a ovelha acaba por se delatar. Na releitura, a historieta cresce. Há no jogo entre o real e a ficção mais complexidade do que a singeleza da fábula inicialmente leva a crer. O logro a que também nós somos lançados tem efeito esclarecedor. Um bom leitor é um leitor que desconfia. O próprio fingimento não é algo simplesmente dado, movimenta-se com a realidade.

Mesmo sob habeas corpus dado pelo disfarce, a ovelha tenta angariar a simpatia do inimigo mais forte, levando-nos a adivinhar nela uma outra 
face mais ou menos escondida: quando diz ao lobo que belos dentes ele tem, imaginamos haver algo de raposa no elogio. Mas talvez seja só um modo desajeitado de tentar passar sem dar na vista o disfarce (um pastor, por não temer os dentes do lobo, pode elogiá-los à vontade; contudo, exatamente por não temê-los, dificilmente tocaria no assunto, que está mais para conversa de ovelha). Pode ser, entretanto, que ela jogue mesmo verde para colher maduro, desconfiada da solidez daqueles dentes. Há também a possibilidade de que tenha se habituado a ser amável com os mais fortes, esperando receber de volta um pouco de delicadeza. Afinal, ovelha e lobo apresentam-se em trajes civis nessa pequena fábula. Mas pode ser ainda que a ovelha se fie nas aparências, como leva a supor o final da história, e, acreditando-se salva, tenha resolvido gozar um pouco, elogiando com a ironia dos que se creem superiores os dentes que noutras circunstâncias seriam a sua perdição. Então o lobo se confessa estropiado, ou apenas bem mais velho e vulnerável do que ela supunha. O tempo passou. Mas até que ponto ele mudou o lobo? Os belos dentes não valem grande coisa porque são postiços. Será que não valem mesmo? Eis que essa segunda aparência, supostamente a verdadeira (um lobo desdentado), leva a ovelha a conclusões falsas: ela pensa poder confiar no lobo, cuja sinceridade, aliás, vale por uma dissimulação, induzindo a ovelha a retribuir com a confissão do próprio disfarce.

A fábula termina por aí, com a ovelha sendo ovelha, e o lobo, lobo. Mas o seu fim de fato acontece um pouco depois, naquilo que o leitor pode adivinhar sobre o desfecho dessa história e que o texto representa, por assim dizer, calando (sugerindo). Artifício e nudez definem o destino da ovelha, mas não o do lobo, cuja confissão não o coloca em risco, garantindo, aliás, o seu almoço. Quer dizer, a confissão do lobo pode ser ou não ser sincera, pois a fragilidade do seu desnudar-se é no caso apenas uma falsa aparência: dentaduras podem devorar ovelhas tanto quanto dentes de verdade, ou apenas mais lentamente (o que pode ser pior). Deve ser por isso que a fábula soa graciosa num primeiro momento, para em seguida nos levar a represar o riso. O lobo perde os dentes mas não o costume nem o apetite. A civilização, no caso, está do lado do lobo, que pode continuar comendo, embora seu fundo verdadeiro, desejável, esteja no gesto igualitário da ovelha, que se mostra verdadeira em retribuição ao que lhe parece (ou é) verdadeiro (mas que em todo caso não tem o sentido que ela lhe atribui, o de confissão desarmada). Sem prejuízo de tudo isso, a fábula - signo sob o qual o livro se abre - nos apresenta dois personagens que são menos do que são, ou do que encenam, o que entretanto logo se dá a ver: um pastor que é ovelha, vale dizer, que não é aquele que cuida do rebanho e sim um 
ser que deve (e não sabe) cuidar de si mesmo, e que está por sinal sem o rebanho; um lobo o seu tanto estropiado.

O fundo verdadeiro da encenação cujas consequências, efetivas, dão cabo da ovelha está no gesto que aponta para a decadência de tudo ou de todos, frisando todavia os diferentes lugares ocupados pelos "sujeitos" nesse quadro. Quer dizer, a pequena peça fictícia, colocando em cena a própria ficção, mas não só ela, mostra em ato que o lugar "histórico" ocupado por seus integrantes, ou o lugar "natural" - entretanto aqui se trata explicitamente de uma segunda natureza -, tem consequências decisivas sobre suas vidas. Poderíamos lê-la como uma comédia (tragédia?) ligeira sobre a posição social dos atores, em discussão nas relações ali encenadas (predador e presa, forte e fraco, superior e inferior), ou, num sentido paralelo, sobre as diferenças concretas entre as consequências do discurso, a depender sempre do lugar (social) de quem o enuncia e de quem é objeto da enunciação. O livro de Vilma Arêas me parece ser sobre tudo isso. Em especial, sobre a premência e sobre as dificuldades de alcançarmos a nossa realidade; sobre os lugares relativos (socialmente determinados) a partir dos quais vemos o mundo; sobre artifício, nudez e expedientes necessários; sobre ovelhas civilizadas e lobos que envelhecem sem se modificar ou sumir do mapa, sobre a vida e a morte.

O primeiro conto de Vento sul, "Thereza", é um retrato da avó da escritora. Em terceira pessoa, a narrativa não esconde o sobrenome do avô, Sant' Anna, que o nome da autora na capa entretanto elide. O relato é e não é pessoal. A singularidade de Thereza está dada desde as primeiras linhas - os extraordinários olhos castanhos desta mulher mignon, cuja pequenez e delicadeza mal combinam com a quantidade de filhos, dezesseis, que deu à luz desde os quinze anos, as pernas sulcadas por varizes azuis, a barriga flácida - e será reposta em todos os parágrafos. ${ }^{3}$ Já no início do texto, o que nela é marcante combina demasia e adaptação, como se tivesse precisado exceder o seu próprio tamanho natural. A tal ponto a vida a transforma que, passados vinte e poucos anos, fica difícil identificá-la a ela mesma na foto dos princípios do casamento. Vale dizer: nela, o ímpar é também uma forma do duplo (Pasta, 2005), pois tudo o que vinca a sua pessoa afasta-a de sua própria imagem anterior, índice de um percurso em que o vivido não compôs uma figura íntegra, antes dissociando-a de si mesma: "Impossível justapor essa mulher já sem frescor ao retrato da jovem esbelta de rosto fino

\footnotetext{
${ }^{3}$ Noutra chave, cômica, a singularidade - agora quase um tique da personagem, igualmente um avesso da individuação bem constituída - aparece em "Fulana", que tem como características especiais "roer as unhas dos pés e das mãos, desconjuntando os membros no ar, como um estranho balé", transar compulsivamente com todos os homens, e "viver várias vidas", como médium, porque uma vida só é pouco.
} 
e cabelos escuros, com blusa de renda e fita de veludo, ao lado do marido e rodeada por seus primeiros filhos, que já eram seis. Devia então contar com vinte e um anos" (Arêas, 2001, p. 15-16, grifo nosso). Essa singularidade não é portanto qualquer, mas negativa, uma soma de menos: nascida na terceira classe de um navio de imigrantes italianos, logo órfã, pois a mãe morreu no parto, foi registrada sem o nome da mãe, o do pai grafado errado.

Viúva aos quarenta e quatro, a vida próspera construída pelo marido, que deixou uma rede de agências de jornais e revistas, deve ter degringolado aos poucos, ou subitamente, pois o que vemos a partir de então é uma pequena sitiante que trabalha duro e fala pouco, cuidando de galinhas e porcos, das hortas e das bananeiras, preocupada com o vento sul, que pode estragar a plantação e pôr a perder a venda das bananas, de onde deve tirar parte do sustento dos filhos. Mesmo a calma e o bom gênio são vistos pela narradora como resultado de subtrações: atributos de quem não tem nenhuma carta na manga ou espaço de manobra. Entre os reveses que lhe coube viver (um bebê morto de febres, o marido morto por erro médico, a filha primogênita, por suicídio, outro filho, por afogamento), uma imagem condensa a resistência de Thereza, experimentada numa situação de dor extrema, ao passo que sugere uma mesma prontidão nos que dela descendem. Trata-se do nascimento de um dos filhos, que veio ao mundo de pé. Sua última marca pessoal é o silêncio que a caracteriza desde a morte do marido. Silêncio e apreço aos ditados, os quais revelam um laborar da autopercepção, um saber petrificado, mais do que decantado, incapaz de agir sobre a sua realidade. Na memória da narradora, a soma de menos é capturada pela suma de um dos que a avó mais gostava de repetir, também ele negativo: "Quem é cativo não ama". Deve ser por seu conteúdo de verdade historicamente configurada - vale dizer, particular porém não excepcional - que, quando ganha voz, ainda que calado, no final do conto, ele comove tanto o leitor.

O que distingue Thereza ao mesmo tempo a aproxima do destino de tantas outras mulheres de sua geração, pertencentes a famílias de imigrantes que vieram tentar a sorte no "Novo Mundo" em fins do século XIX. Isto é, possivelmente o grau de concentração dos traços que a literatura recolhe e unifica ajuda a dar à personagem uma feição ímpar; no entanto, não há como não notar que a sequência de acontecimentos marcantes por ela vividos são de natureza objetiva. Por outra, a singularidade aparece como um traço cuja matriz histórica fica indicada. E se seu caráter singular extravasa uma grande força, resultante do que ela soube fazer de tantas outras vulnerabilidades, essa força nada tem de redentora afinal. A trajetória de sobressaltos e a proximidade com a vida e o trabalho diários 
- o caráter assim constituído, mas não em benefício próprio - levam a questionar do que é feita essa singularidade da avó: novamente, um processo de individuação que se configura como capacidade (física, moral) de resistir às adversidades; um conjunto de potencialidades individuais que não se traduzem em realizações, antes em reações. Desse modo, aqui, a força pessoal aponta sempre, simultaneamente, para uma fraqueza maior do que a personagem. Num dos únicos momentos do relato em que se pode adivinhar alguma alegria em Thereza, ela coloca tijolos no chão para dar altura à neta e segura com ela o pilão para lhe transmitir o ritmo do trabalho. A cena tem paralelo na perplexidade dessa avó ao entrever na menina já crescida alguma liberdade de decisão sobre o próprio destino. Pode ser que os tempos mudem para melhor.

O segundo conto, "República Velha", traça a figura de um lobo desdentado. O coronel Caetano Padilha perdeu os dentes nas trapaças da política e nos desarranjos da vida amorosa. As dentaduras, por certo, ainda mordem. Em linha de continuidade com a primeira, esta narrativa voltase para o passado. O título da seção, "Matrizes", faz pensar numa história familiar, entretanto pode ser também familiar ao leitor, a nós, brasileiros. Em terceira pessoa, o narrador não se mostra; prefere mostrar de perto as cenas, cujo teor de violência não é estranho a quem lê, mas pede estranhamento. Trata-se de ver à distância o velho conhecido, que não é inteiramente nem uma coisa nem outra. Talvez seja esse o seu apelo contemporâneo, num tempo outro em que a violência, muito mudada, ainda é o nosso nexo social. A brutalidade dentro da família, não um reduto e sim uma parte da sociedade violenta, está por exemplo nas práticas diárias de Paulo Honório, em São Bernardo, um personagem dos "novos tempos" da revolução de 1930 e da modernização brasileira, apontando para o que se modifica em nosso país sem se transformar substancialmente.

A esposa do coronel Padilha é uma figura desenhada à sombra, o que no conto dá forma não apenas à autoridade do marido. Ironicamente, em plena luz do dia, justo quando o coronel acabava de recuperar a sorte nos negócios com o gado e o ano parecia começar com o pé direito, ele a apanha com outro homem. Carlucho, "um escuro de nascença contratado para trabalho de tocaia contra um vizinho salafrário", toma o seu lugar na cama, no quarto do casal. Num piscar de olhos, a imagem é a de um outro que emerge como um duplo do coronel, sendo imediatamente assassinado por ele, junto com o seu cão. Resta a mulher; sem nome no conto, ela é apenas "a mãe de vocês", e no final, como o coronel diz aos filhos, a "puta". Também ela não era apenas o que aparentava, dona obediente, de bem com Deus, pois escondia nos olhos de porcelana a proximidade 
com a "gentinha de cor". No jogo entre claridade e sombra - com parte nas oposições ignóbeis entre o "branco" e o "negro", pois as imagens do conto têm fundo social e se enraízam na perspectiva do proprietário -, no jogo entre o que se esconde e o que se mostra, vêm à tona os conteúdos recalcados da família brasileira, a saber, ali, a sexualidade da mulher, a persistência da escravidão e a presença do "criminoso doméstico" como o outro do mandão local.

Encoberta pela autoridade do marido, a singularidade dessa mulher está dada por um gesto decisivo, tão insubordinado quanto furtivo, pelo qual é condenada à ignomínia. O que se segue é um espetáculo de humilhação, a desforra dia e noite, segundo a qual (na claridade e na escuridão, no avesso e no direito submetidos a exposição pública) ela é obrigada a velar, no terreiro da propriedade, a colcha manchada com o sangue do amante, sem licença de se afastar nem para as necessidades. Depois, fraca, imunda como a colcha que, apodrecida, se desfez no tempo, ela recebe duas bofetadas na cara e é expulsa. Enlouquece, envelhece cem anos, está pronta para ser aceita de volta. O que ele fez foi pouco, mas passado bastante tempo pode ser suficiente para perdoá-la. Ou para usá-la, no lugar de outras "putas".

A narrativa vê o todo na parte, ou o maior no particular - a "República Velha" está na casa. Inclusive nos filhos, que arrefecem à primeira ameaça de perder a herança. Talvez esteja ainda mais dentro, no narrador calado, no leitor que, como os locais, assiste às cenas de humilhação da mulher e acompanha a lógica incontestada do proprietário. Isto é, a brutalidade tem forma no conto e nos submete, a todos, à mente do coronel. Nesse sentido, o foco narrativo e a perspectiva dramatizam algo que voltará a aparecer no livro: nossa pesada herança histórica, a posição do intelectual diante dela, a parte do leitor esclarecido. $\mathrm{O}$ mal-estar diante da última palavra, (por verossimilhança) dada ao coronel - que tempos depois de matar a cobra mostra mais uma vez o pau para dizer que vai chamar a mulher de volta ("Vou chamar a mãe de vocês de volta. [...] Puta por puta fico com ela que já estou acostumado", p. 25) -, é um efeito produzido pela posição social dessa fala, cuja brutalidade é um apanágio do proprietário, pois um objeto não se perde, e ele não vive bem sem ela, ou, como diz, o que é do homem o diabo (o homem negro?) não come. Tal grau de violência não chega até o leitor somente como um eco do passado morto. É de pé que o fantasma que não deu a volta por cima e precisa da mulher agride seus filhos e também a nós.

A continuidade da violência de classe e as dificuldades de sua superação pelo conjunto da sociedade, o sentimento profundo dessa cisão, reen- 
contrada dentro da subjetividade, revêm de modo imprevisto na narrativa seguinte, "Linhas e trilhos". O cenário é diverso, o país mudou, contudo um lobo imaterial - tão forte quanto outro bem palpável -, a ditadura militar que nesse momento mostra seus dentes. ronda a narradora. Ou melhor, surpreende-a em autoimagem. Como em poemas de Drummond (Andrade, 1992), defrontar-se com o seu outro de classe é ver-se aos olhos dele. A figura devolvida por tal espelho costuma não ser aprazível e, à guisa de vingança histórica, leva o eu poético a flertar com a autodestruição. No episódio narrado, porém, o autoconhecimento se dá numa direção inesperada, pois o que se desvela são limites subjetivos e objetivos à aproximação, que entretanto se dá, de modo dilemático, abrindo campo para a reflexão.

Vale observar que o desencontro fundado em diferenças de classe está noutras narrativas: no affaire entre supervisor e funcionária em "Lugar-comum", ele, dono do expediente dela, ela, interessada na boa vida prometida pelo céu azul dos olhos dele; ou em "No fundo do rubi", na pontada de má consciência de um sujeito que decide tirar uma mendiga das ruas durante uma noite. Mas é sem dúvida em "Linhas e trilhos" que o jogo de cena entre as classes ganha outra dimensão e o teor de violência a ele inerente encontra força. Na voz da narradora, a dimensão reflexiva do relato é mais espessa do que nas outras narrativas; um retorno a si mesma, anos depois, que entretanto leva a reconhecer o corte entre "eu" e "outro", e, portanto, a estranha natureza de uma identidade - a da elite e também a dos intelectuais, no meio de campo - que no contexto brasileiro se fez à custa de distância social, o que não deixa de ser verdade mesmo quando a disposição é combativa.

Uma professora, militante de esquerda, conhece um gari durante um trajeto no trem da Central. Sente-se atraída por ele, que corresponde, mas colocando-a na pele de outra pessoa, uma mocinha sobreposta à feminista. A singularidade de ambos sobressai e ao mesmo tempo encontra o seu limite no encontro. Como num lance de espelhos, cada um é duplo do outro, aqui justamente um outro de classe, conforme evidencia, aliás, o comentário contrafeito da professora sobre a identidade do sobrenome deles, Santana/Sant'anna. Na voz (provavelmente) da policial que a interroga depois, indagando sobre uma foto em que há seis ou sete "suspeitos" amontoados num trem, a raiz histórica das diferenças é nomeada com violência própria ao país escravocrata: "uma branquela metida com um negro azul de tão retinto". O olhar, externo a eles, está também neles, ainda quando em busca justamente de cortar distâncias: o galanteio não dispensa o introito descriminalizante; Laudelino se apresenta mostrando os documentos para que a professora veja com os próprios olhos que se 
trata de um trabalhador. Procurando disfarçar o que salta aos olhos - a diferença, socialmente instalada entre os dois -, e que Laudelino não apenas supõe como expõe ao aproximar-se com os documentos nas mãos, ela comenta: "Será que somos parentes? Seu sobrenome é igual ao meu, só que escrito diferente" (p. 31, grifos nossos). Passam a se encontrar no bar da estação, onde outros constrangimentos povoam a cena. Ele toma cerveja e pede à garçonete "leite para a moça". Machismo ou delicadeza? Ela disfarça a humilhação "depois de tanta panfletagem defendendo igualdades". A insuficiência da superação individual das distâncias, e contudo a necessidade também individual de vencê-las, as limitações objetivas, imprevistas pela vontade aparentemente livre, o lugar oscilante do intelectual (Arantes, 1996), premido pela luta política, solidário às classes baixas e dando-se conta das marcas de sua própria extração social, são algumas das questões em pauta na narrativa. A professora leciona num colégio que fica num bairro operário, cujo diretor tem orgulho de servir às autoridades, fiscalizando e entregando por nada meninos desdentados. A brutalidade do diretor, amparada pelo Estado, e vice-versa, a violência do serviço social (que lhes arranca os dentes por falta de verba para tratamento), repetem-se em ponto menor na esfera doméstica, contaminando tudo e todos (veja-se o episódio da mãe analfabeta que espanca o filho porque um vizinho bêbado lhe diz que era isso que mandava fazer o bilhete enviado a ela pela professora).

As linhas cruzadas que abrem o texto mimetizam possivelmente esse difícil trânsito entre pessoas de classes diferentes, ao passo que dão igualmente contorno ao emaranhado em que se transforma a mente sob constrangimento policial. Herança histórica e história contemporânea enovelam-se. Por outro lado, o esforço de puxar pela memória e esclarecer o passado - cruzando "isso com aquilo", estabelecendo nexos por todo o texto - tem evidentemente parte com o desejo de superação das diferenças e brutalidades, definindo o sentido de rememorar, narrar, abrir caminho. Trata-se de um impulso que move a narradora (assim como movimenta as perspectivas e suas consequências), a qual, não por acaso, também só se constitui no meio do texto, no trato com um material bruto que se expõe, por assim dizer, em terceira e primeira pessoa, com vozes entrecortadas, instruções para depor e sair vivo, um poema de um condenado a prisão perpétua. Isto é, há um material coletivo nessa memória individual.

Igualmente de ímpeto totalizante, ou melhor, de movimento da reflexão à procura de fazer relações entre episódios diversos, entre momentos diversos da história, é o modo pelo qual o texto faz do cruzamento de linhas paralelas 
um método. ${ }^{4}$ Se tudo isso puder ainda ser chamado de artifício literário - a técnica de montagem das cenas, de cruzamento de vozes, épocas, a oscilação da narradora entre "eu" e outro, primeira e terceira pessoa -, fica claro que a literatura, aqui, é uma forma de aproximação à realidade, a qual não está dada. O entrecruzamento de duas violências, a dos interrogatórios sob a ditadura e a das diferenças sociais que atualizam a herança escravocrata, é uma força da narrativa, que aponta para a reposição do que não foi superado. Daí, simbolicamente, os mortos, em todos os cantos do livro, que não acabaram de morrer. Na perspectiva do conto, a violência, como já ficou sugerido, aparece "do lado de fora" - aos olhos da polícia política, seis ou sete, "quase todos negros, mas também pardos e um puxando pra branco", são naturalmente suspeitos, embora pareçam apenas um grupo a caminho do trabalho -, uma "exterioridade" cujo correspondente interno é passado em exame corajoso pela militante, na voz da narradora: “Com certeza pensavam que ela não passava de uma branca querendo faturar um negro. E ele? Querendo também faturar uma branca com lucros calculados?" (p. 32). Um entrecruzamento paralelo dá forma à convergência de interesses para além da divisão de classes, ou à possibilidade de trabalho coletivo na luta por uma sociedade mais justa - uma possibilidade aberta pela luta política naquele momento, que a narrativa reconvoca à cena. Trata-se de mais uma trilha nos episódios que se cruzam nesse conto: na foto tirada na plataforma da estação, um dos "suspeitos" era "igual a Laudelino"; pela época talvez fosse impossível ser ele, mas "ela", a personagem de quem a narradora se aproxima, tem dúvidas (era "igual" a Laudelino por causa da cor da pele? Ou por uma confusão da memória afetiva, que o coloca a seu lado na luta política?); o fato é que tal confusão faz relembrar o momento em que ela e uma colega tiveram de transportar pelas ruas do Rio de Janeiro um mimeógrafo. Por um acaso feliz, um gari as salva, escondendo o objeto em sua carrocinha. "Trabalho sujo" e "trabalho sujo" se unem, como se a imagem encontrasse seu corpo social desejável. A cena que dá novo sentido ao jogo entre o que se esconde e o que se mostra é por assim dizer o positivo daquela outra, anteriormente narrada, em que os "suspeitos" da foto são negros, ou por sua extração social são "como se fossem negros", o quanto basta para desconfiarem deles, ainda que só dois estivessem "realmente visíveis, porque havia muitas sombras e a luz deslumbrava" (p. 27).

\footnotetext{
${ }^{4}$ A história, assim, saturada de tensões repostas a cada cruzamento, é vista como sequência de "agoras" que interceptam narradora e leitores, de tal modo que a não linearidade da narrativa sugere uma visão materialista do processo histórico, no qual imagens do passado voltam a falar ao presente, e vice-versa. Um símbolo sugestivo de tal temporalidade rediviva, detendo o tempo "que passa", comparece na fala da narradora: "Hoje é como um relógio quebrado, não tem antes nem depois". Ver, ainda, Benjamin (1993b).
} 
Afinal, a professora decide "mudar de assunto e [se] livrar do grande problema" (p. 31). Mas nem assim para de oscilar. As tardes crescem, Laudelino insiste, ela não deixa de ir aos encontros, mas "por trás da beleza vinha [ainda] a desconfiança" (p. 32). Em relação a ele ("não te conheço"), e a si mesma (o que ela queria com ele? "Se prevenia com todas as forças contra o perigo do erro"). Por fim (mas ainda não o ponto final), diz não. O ponto final é a consciência da própria cisão - "na relação com o mundo as rimas são sempre interiores", diz o poema do condenado, que volta à sua lembrança - e do quanto ela reflete as condições materiais de um mundo desigual, que se interpõem entre os (im)possíveis amantes: enquanto escreve, a ex-militante imagina que provavelmente Laudelino não teve uma vida longa como a sua. "Eu acho que ele já morreu" (p. 33).

Se as cisões da sociedade contemporânea passam dentro do sujeito, se o que está fora está dentro, esse é o fio que nos leva às narrativas mais interiorizadas do conjunto, por vezes quase poemas, ou prosas no limite: entre vigília e sonho, organização épica do vivido e canto dissolvente, perda e beleza. Aqui, a realidade recuou para o sonho. As imagens, ora distantes do chão, ora literalmente rastejantes, são o próprio fio em que alguém arrisca apoiar os pés, ou apoiar-se todo. A memória então se movimenta num terreno muito frágil, pois sabe "que qualquer sopro [pode] desfazer os corpos mantidos inteiros [em seu] oco" ("Persistência da memória", p. 54). Como se, rastejando devagar ou pisando leve para não acordar ninguém, esses textos procurassem testar o quanto ainda há de realidade na beleza que foi expulsa do mundo. Uma beleza feita, entretanto, de perdas. Não por coincidência são linhas que frequentam a morte, o contorno tênue entre o morto e o vivo, entre vida e ilusão, água e terra.

Nessas peças poéticas trazidas pela memória ${ }^{5}$ - ou antes o contrário, pois é a poesia uma espécie de camada entre o vivido e as perdas, separando-os, comunicando-os -, o fundo parece exercer pressão sobre as técnicas de montagem dos textos, de tal modo que entrevemos a luta da subjetividade para atravessar a si mesma. Conhecer-se, relembrar-se, desmembrar-se num outro: um morto ou uma parte do passado. Em alguns desses textos, o parentesco com procedimentos surrealistas salta aos olhos, e embora extremamente subjetivos, nota-se a falta de um "eu". Como escreveu Walter Benjamin sobre aquela vanguarda, aqui "a linguagem tem precedência". "Não apenas precedência com relação ao sentido. Também com relação ao $\mathrm{Eu}$. Na estrutura do mundo, o sonho mina a individualidade, como um dente oco" (Benjamin, 1993a, p. 23).

\footnotetext{
5 "O rio", "Encontro", “À queima-roupa", "Persistência da memória”, que parecem fazer conjunto com “A letra Z", "Paixão de Lia", "Sister 1982", "O morto e o vivo: anotações de uma etnógrafa".
} 
Nos mais radicais, "Encontro", "À queima-roupa", "Persistência da memória", "Habitar", a dificuldade de se identificar um "eu", ou uma subjetividade que se possa chamar pelo nome, está posta desde a sintaxe: sabemos, no máximo, que há um "ele", um "ela" (num tempo reverso, como o de um pai menino sob o olhar da filha adulta, a qual se vê criança, desenhada pelo menino), mas quem são? Ou quem é o sujeito dessa linguagem tateante que acompanha outro sujeito, oculto, que "abriu a névoa da praça com as duas mãos”, "abraçou a casa”, "abraçou com cuidado as taças e vidraças para que não se partissem" (p. 51)? Ou aquele outro será outro, que "começou a cavar [noutro texto] no muro uma passagem que do jardim levasse ao interior" e, pronta a tarefa, "esperou a noite para rastejar através do túnel" (p. 53)? Num contexto muito distante das vanguardas, como é o caso, não será demais perguntarmos sobre a inquietação que tais textos despertam em sua resistência ao tempo presente e em seu profundo subjetivismo desindividualizador. Até onde posso ver, não estamos aqui diante da afirmativa de um subconsciente libertador em contraposição à razão (ou às suas promessas não cumpridas). O sonho e a rememoração, semelhantes nesses textos, não abrem brechas ao mundo desperto, pelo contrário, cavam a sua terra, sobrevoam suas paisagens por não conseguirem vencer as distâncias, aproximarem-se. Neles, a memória, como se fosse de outrem, de fato alheia, é o impenetrável que alguém (algo?) tenta rastrear. Distantes da dimensão de combate do surrealismo europeu, a fantasmagoria é a sua conexão com o mundo desperto, mas de tal modo que ainda é possível estranhá-la, dar pela falta da vida, o que a presença da beleza vem assinalar. De resto, a consistência das imagens não deixa dúvidas sobre o caráter de tal poética, seu aceno quase sobrenatural: a camisa branca do pai suicida ("Zeca e Dedeco"), ondulando pendurada nos galhos à beira-mar horas depois, quando o sol já se pôs e apenas um resto de luz flutua no ar; a presença do amigo, sempre marcada por uma sensação de ausência ("O rio"); o encontro com o rosto querido de um pai menino (aquele mesmo suicida), esquecido pelos seus na gare sem que ninguém ligasse muito para aquele esquecimento ("Encontro"); o intruso que vira para a janela, de onde se vê a mulher de pedra deitada nas montanhas, o cadáver cheio de sonhos e lembranças ("À queima-roupa").

Em chave alegórica, "Habitar" põe a nu o eixo compositivo desses textos, a fantasmagoria de sujeito e mundo. Dando existência material ao que a fantasia pode compensar - ou justamente não pode -, "ele" aumenta a própria casa à medida que ela se despovoa, amplia os espaços à proporção que perdem o uso (varandas, puxadinhos para ninguém, garagem duplicada depois que os carros explodem junto com seus ocupantes), 
tornando-a a própria transposição espacial das ausências que testemunha. O ímpeto de enfrentamento, porém - a obra que "ele" toma a peito "contra a vertigem da falta" -, traduz-se definitivamente em aporia, uma vez que em sua obsessão construtiva "ele" só olha adiante (embora pareça sempre olhar para trás). "Ele amplia e ao mesmo tempo despreza a casa, não liga para a conservação" (p. 55); assim, enquanto corre para alcançar as perdas, construindo, perde o que, pronto, começa de fato a ruir: "Agora os maus-tratos, o relaxamento, os pregos enfiados nas paredes rasgam a pintura, deixam ver o reboco. Este é o ponto frágil da fantasia, que funda o absurdo, porque no intimo ele sabe que a vida não vive" (p. 85, grifos meus). "No novo cenário, formigas e bichos invisíveis soltam guinchos e pios, fazem ninhos pelas frestas e rachaduras [...]. Ratos chiam no porão" (p. 56-57). Pessoas, - ou serão vultos? - continuam atravessando a casa, mas sem pertencer a ela, uma presença, também a dos seres, feita de ausências, de tal modo que o espaço e seu habitar ("morar", "estar presente", "permanecer") compõem uma imagem em que o que já foi ganha existência e peso, com uma força incontornável, para desfazer-se em seguida, de resto saindo do campo de visão antes mesmo de desaparecer.

O significado do enigma nos remete a uma particular experiência da história, que passa ao largo da consciência desperta, se ainda for possível chamar de história essa memória desvanecente e sua exemplaridade ruinosa, cristalizadas na alegoria - por assim dizer, o resíduo da "vida [que] não vive". A permanência da casa, sempre em movimento, remete aqui a um verdadeiro trabalho de Sísifo, como se apreender a própria existência ("estar presente") tivesse se tornado uma tarefa infinita: mais do que um impulso, uma condenação. Essa singular relação com o tempo é também ela regida pela duplicidade, pois o que ficou para trás (as ruínas da casa para as quais "ele" não se volta) retorna adiante como fantasma. $\mathrm{O}$ "sujeito" correspondente a essa história é esse construtor cegamente obstinado com o qual o ponto de vista da narração mantém uma relação afetiva, irmanado-se, numa espécie de anfibologia, possivelmente a indicar que o que é pessoal, sem prejuízo do caráter excêntrico dessa obstinação construtiva/ destrutiva, não é apenas idiossincrasia.

Entre tantas sombras, também aqui não sabemos ao certo de quem são as lembranças: "dele", que talvez seja o pai, hoje envelhecido, do desfecho do texto; de alguém que dele se lembra, quando também "ele" está e já não está ali, com os cabelos de neve que "não derretem jamais"; desse pai, talvez não envelhecido e sim morto, que sem olhar para trás "permanece de pé, vestido com a suéter tricotada pela mulher morta". Seja como for - e essa ambiguidade é mais uma vez constitutiva desse conjunto de 
textos -, nenhum sujeito aparece por inteiro e todos, por contaminação metafórica, parecem vestir aquela mesma morte. Em suma, um subjetivismo desindividualizado que não deixa de ser o avesso, correspondente, daquelas singularidades negativas dos primeiros contos, vincadas pela falta, a qual, ali, palmilha o seu chão histórico.

( $\mathrm{O}$ fio estirado entre a potência da linguagem nesses textos e a realidade que dela emerge como impossibilidade de configuração de uma subjetividade nos leva de volta à questão inicial sobre o desvendamento do artifício, a desliterarização da literatura. Se Vento sul inclui procedimentos variados na indagação da experiência vivida - dos mais desliterarizados aos mais poéticos, com resultados não homogêneos -, ele coloca em jogo de espelhamento e autoindagação a verdade da arte, seu fingimento, e a (in)capacidade de apreender a "mentira" do real. No desejo de conhecer a realidade, a verdade da mentira movimenta a mentira da verdade, e vice-versa. Ainda assim, o intervalo entre uma coisa e outra pede maior investigação.)

\section{Referências:}

ANDRADE, Carlos Drummond de (1992). Poesia e prosa. 6. ed. Rio de Janeiro: Aguilar.

ARANTES, Paulo (1996). Paradoxo do intelectual. In: Ressentimento da dialética. Rio de Janeiro: Paz e Terra.

ARÊAS, Vilma (2011). Vento sul. São Paulo: Companhia das Letras.

BENJAMIN, Walter (1993a). O surrealismo. O último instantâneo da inteligência europeia. In: Obras escolhidas I: magia e técnica, arte e política. 6. ed. São Paulo: Brasiliense.

(1993b). Sobre o conceito da história. In: Obras escolhidas I: magia e técnica, arte e política. 6. ed. São Paulo: Brasiliense.

CARONE, Modesto (1998). Resumo de Ana. São Paulo: Companhia das Letras.

JOGO de cena (2007). Direção: Eduardo Coutinho. Produção: Bia Almeida et al. Rio de Janeiro: Videofilmes. 1 DVD (100 min).

\section{Bibliografia complementar}

XAVIER, Ismail (2012). Ways of listening in a visual medium. New left review, London, n. 73, p. 97-116.

Recebido em novembro de 2012.

Aprovado em janeiro de 2013. 


\section{resumo/abstract}

Uma realidade que ficcionalizou a si mesma: história e subjetividade em Vento sul, de Vilma Arêas

Ana Paula Pacheco

O artigo busca compreender como se dá a representação da realidade no livro Vento sul, de Vilma Arêas, a partir da indagação de procedimentos simétricos opostos de composição nele radicalizados: a desliterarização e o artifício poético-literário. Trata-se de apreender o teor da história e do sujeito que o livro configura, e de refletir sobre um veio da literatura brasileira contemporânea.

Palavras-chave: Vilma Arêas, Modesto Carone, Eduardo Coutinho, forma artística e processo social brasileiro, realismo e realidade.

\section{A reality that ficcionalized itself: history and subjectivity in Vento sul, by Vilma Arêas}

Ana Paula Pacheco

By investigating symmetrical opposite proceedings of compositional techniques radicalized in Vento sul, by Vilma Arêas - the non-literariness and the literary-poetic device - this article attempts to understand how the representation of the reality works in it. We try to grasp the content of the history and the subjectivity formalized by this book.

Keywords: Vilma Arêas, Modesto Carone, Eduardo Coutinho, artistic form and Brazilian social process, realism and reality. 